\title{
INFLUENCE OF FORM AND SIZE OF A ROOT ON THE STORAGE LIFE OF TABLE BEET
}

\author{
Ludmila Pusik \\ Department of Technologies of Processing and Food Production \\ Ludmilap@gmail.com \\ Vladimir Pusik \\ Department of Agrotechnology and Ecology ${ }^{l}$ \\ kysmish@gmail.com \\ Veronika Bondarenko \\ Department of Agrotechnology and Ecology \\ zim-hot@rambler.ru \\ Ludmila Gaevaya \\ Gaevaaludmila9@gmail.com \\ Nina Lyubymova \\ Department of Forest Management and Life Safety \\ nina.lioubimova@gmail.com \\ Galyna Sukhova \\ Department of Crop Production ${ }^{3}$ \\ syhovagalinaiv@gmail.com \\ Nataliya Didukh ${ }^{2}$ \\ Natashadidukh@ukr.net \\ Galina Slobodianyk \\ Department of Vegetable Growing \\ Uman National University of Horticulture \\ Institutska str., 1, Uman, Ukraine, 20305 \\ sgy123@i.ua
}

${ }^{1}$ Kharkiv Petro Vasylenko National Technical University of Agriculture

44 Alchevskih str., Kharkiv, Ukraine, 61002

${ }^{2}$ Department of Fruit and Vegetable and Storage ${ }^{3}$

${ }^{3}$ Kharkiv National Agrarian University named after V.V. Dokuchaiev

township Dokuchaevskoe, Kharkiv distr., Kharkiv reg., Ukraine, 62483

\section{Abstract}

Table beet have a series of high-value parameters: good taste properties, healing-prophylactic importance, ability to longterm storage. There are many sorts of table beet, different by root form. Most widespread are ones of the round and cylindrical forms. At the same time plants of table beet at growing form roots of different masses. The aim of the study was to investigate the storage life of table beet depending on form and root sizes. The conducted studies give a possibility to substantiate scientifically an influence of table beet' form and sizes on their storage life for determining its term.

It has been established, that roots of the round form of the Kharkiv Bordo sort lost moisture more intensively at the expanse of breath and evaporation -4.4-5.4\%. In the Vital sort with roots of the cylindrical form, mass natural losses were 4.1-5.1\%. At that more natural mass losses were in small roots with mass 150-300 g.

Small roots were more inclined to sprouting at storage. Among sprouted roots, $1.6-1.8 \%$ were small ones with mass 150 $300 \mathrm{~g}$. More percent of sprouted roots was for ones with mass $500-700 \mathrm{~g}$ as $2.3-2.5 \%$. At that less percent of sprouted roots was in 
the Vital sort of the cylindrical form.

Small roots with mass $150-300 \mathrm{~g}$ were more damaged by rots at storage $-10.4-12.3 \%$. Among roots of middle sizes, $6.0-$ $6.8 \%$ were damaged by roots, among big ones $-4.5-4.7 \%$. It must be also noted, that cylindrical roots of the Vital sort were less damaged by rots at storage than round ones of the Kharkiv Bordo sort.

Keywords: table beet, sort, storage, root form, root mass, losses.

DOI: $10.21303 / 2504-5695.2021 .001756$

\section{Introduction}

Consumption of fresh vegetables is extremely important for normal human life activity. It is explained by the fact that even with a small amount of dry substances, contained in juicy vegetable products, the human organism receives biologically active compounds, necessary for metabolism, life activity support, health and life prolongation. At the same time the modern production volume of fresh vegetables doesn't satisfy growing needs of the population. According to physiological norms, table beet consumption is $10 \mathrm{~kg}$ [1]. Continuous supply of consumers with fresh roots is complicated by the season character of production and long storage of the products. Scientists' researches demonstrate that long-term storage of vegetables is accompanied with quality and quantity losses, content decrease of biologically active substances. The world experience of vegetable growing testifies that at shortcomings at harvesting and without additional processing of products at passing through the logistic chain, $35 \%$ or one third of the harvest of fresh vegetables is lost [2].

So, the problem of vegetables storage combines a wide circle of questions. It is important to know the complex of causes, conditioning products losses, namely planting, harvesting, transportation, sort peculiarities, optimal regimes and best storage methods $[3,4]$.

Many complex studies as to increasing the roots stability at storage were conducted, but several questions still unsolved. One of main factors, decreasing the commodity quality of roots and causing great losses at their transportation and storage, are elements of after-harvesting processing of products, namely sorting by root sizes.

At storing any juicy product, it is always necessary to base on its biological characteristic. All roots, excluding radish, are biennial crops. Their general biological peculiarity is to stay at a low temperature at rest that is not deep, but rather forced for roots. At satisfactory conditions their growth recovers. The biological function of the rest condition is differentiation of a cone of root buds growing, their preparation to reproductive development. The period, during which buds finish this preparation, determines the rest duration that is storage life of products [5].

Economic-botanic sorts of table beet differ by form, coloration and flesh structure, ripeness term, favorableness to ageing [6, 7]. Sorts belong to five sort-types (Egypt flat, Egypt round, Bordo, Eclipse and Erfurt), each of which combine several economic-botanic sorts [8].

The storage life of table beet depends on root form. The storage life of sorts with flat roots is satisfactory, they ripen fast, their flesh is mainly violet-red with more or less expressed white rings, taste is good, dry substances content is 8-11\%. At early spring sowings they are grown for summer consumption, and at ones at the end of May - for autumn and early winter one. These sorts are not much suitable for long-term storage. Ones with the round-flat and round root forms are most suitable for that. They ripen a bit later than flat ones, contain 10-12\% of dry substances, have good taste qualities, are well stored, are less sick, have less natural losses and are stored longer without sprouting. These sorts include the Bordo sort-type and other. Sorts with conic roots contain 12-16\% of dry substance, are stored well, but have a low quality, because contain much cellulose and have the fibrous flesh. They include Erfurt sort-type. These sorts are little spread [9].

Table beet sorts are recommended to be harvested at the stage of technical ripeness, coming in 84-150 days after sprouting. There are also recommendations for harvesting roots as 
needed or at reaching necessary sizes [10]. It must be noted, that the storage life of juicy products of root plants depends on conditions and methods of storage [11-13]. For long-term storage it is recommended to use table beet with the most cross diameter from 5.0 to $14.0 \mathrm{~cm}$ [14].

Studies have established that vegetables, different by sizes of the product organ, are stored unequally. Thus, the storage life of bush pumpkin fruits depends on fruit size. Under conditions of raw material ground at daily temperature $26 \ldots 30^{\circ} \mathrm{C}$ fruits with a diameter more than $8 \mathrm{~cm}$ are stored during $13-18$ days, diameter $4.5-6.0 \mathrm{~cm}-2-6$ days. At temperature $5 \pm 1{ }^{\circ} \mathrm{C}$ fruits with diameter $4.5-6.0 \mathrm{~cm}$ are stored during 5 days, diameter $6.1-8.0 \mathrm{~cm}-13-$ 16 days, the mixture of fruits with this size - 10-12 days, and ones with diameter $8.1-10.0 \mathrm{~cm}-$ 18-21 days. The mass loss of fruits at storage at temperature $5 \pm 1{ }^{\circ} \mathrm{C}$ by $42 \%$ depends on their size. The output of commodity products by $22 \%$ depends on fruit sizes [15].

Under usual refrigerator conditions cucumbers in an open box preserve their properties during two days, more natural losses are observed in fruits with length 91-110 $\mathrm{mm}$ than in the mixture. Cucumbers are stored almost two weeks practically without losses at temperature $5 \pm 1{ }^{\circ} \mathrm{C}$ in boxes with a polyethylene film or in polyethylene packets of $20 \mathrm{~kg}$. Average daily losses of fruits at their storage in polyethylene packets don't exceed $0.08-0.10 \%$ [16].

A harvested batch or one package may contain fruits, different by sizes within the same sort. Thus, their breath efficiency is different. The studies testify that more breath intensity is inherent to small bush pumpkin fruits, because metabolic processes are more intensive in them. With increasing the fruit size, the breath intensity decreases. The breath intensity of small fruits is five times higher than in big ones, and in middle - two times less than in ones with a less diameter [17].

Products of small bush pumpkin fruits must emit 4.3 times more heat than ones of middle sizes, and 8.1 times more than big ones; cucumbers with length $91-111 \mathrm{~mm}-$ in 1.3 times more than ones with length $111-140 \mathrm{~mm}$. The cooling speed of pumpkin fruits to the storage temperature depends on their size. Small melon fruits are cooled to storage temperature $5 \pm 1{ }^{\circ} \mathrm{C}$ during 17 hours, bush pumpkin -7 , cucumber -1.5 hours, middle melon fruits -24 hours, bush pumpkin -8.5 hours, big melon fruits -25.5 hours, bush pumpkin - 14.5 hours $[18,19]$.

Any batch of table beet is a heterogenic mass of roots of different sizes, so of different ripeness. In this connection the intensity of physiological processes depends on root size. Such batch is difficult for storage.

For establishing the optimal storage temperature for table beet as $0 \pm 0.5^{\circ} \mathrm{C}$, it is necessary to eliminate heat, formed as a result of roots breath and their heat content.

For decreasing losses of stored roots, it is necessary to keep the optimal temperature regime at the expanse of heat removal from them, by regulating amounts of ventilating air. For example, lately ripening radish sorts of big fruits have almost 2 times more specific surface area, comparing with early ripening ones with small fruits, that positively influences the natural mass loss at their storage. The cooling speed of roots from $20^{\circ} \mathrm{C}$ to the optimal storage temperature $\left(+1^{\circ} \mathrm{C}\right)$ depends on their diameter. Radish enthalpy doesn't depend on root size. Physical and thermal properties of roots are determining factors of their storage economic efficiency [20].

So, the research aim follows from the presented data - to study the table beet storage life depending on roots' form and size.

\section{Materials and methods for studying the intensity of natural mass losses of table beet at storage}

The studies were conducted with table beet sorts Kharkiv Bordo and Vital of middle ripeness, Ukrainian selection (Institute of Vegetable and Melon Growing of the National academy of agrarian sciences of Ukraine).

Kharkiv Bordo is a sort of universal destination, middle ripeness, the vegetation period is 130-133 days. A root is round-oval, with dark-cherry coloration, core without rings, with perfect taste qualities (Fig. 1). Roots are well stored till spring, are stable to white and gray rots, have a perfect commodity outlook. 
Vital is a sort of universal destination, middle ripeness, vegetation period is $130-$ 138 days (Fig. 2). Roots are of the cylindrical form with a small acute tip, their diameter reaches 5-7 cm. The flesh is of dark-red color with a dark-violet tint, sweet, juicy, without expressed white rings. Roots are characterized by good transport ability.

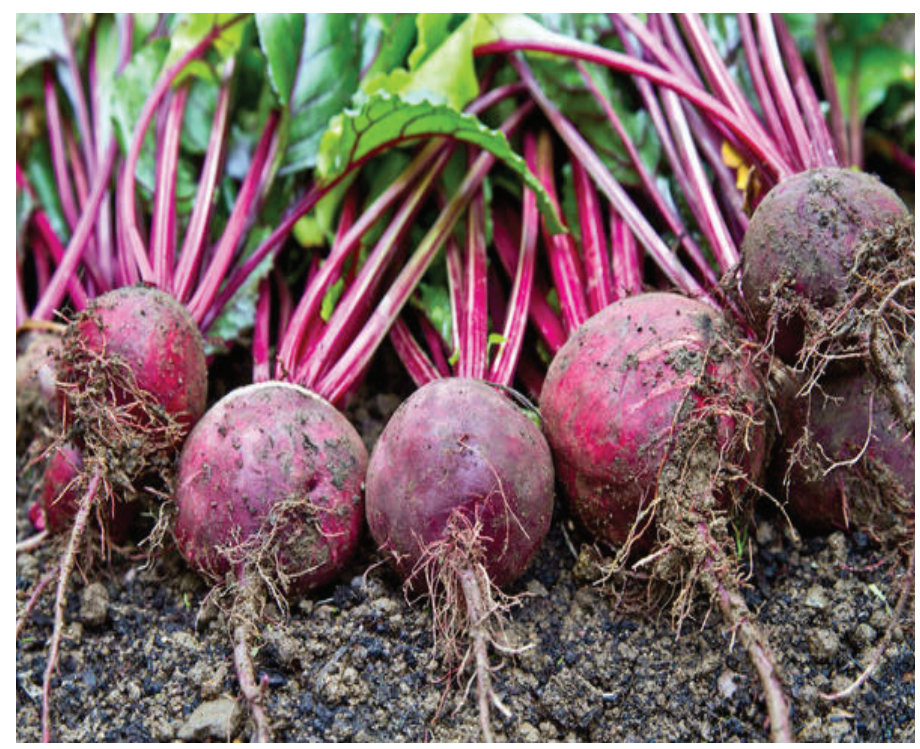

Fig. 1. Kharkiv Bordo

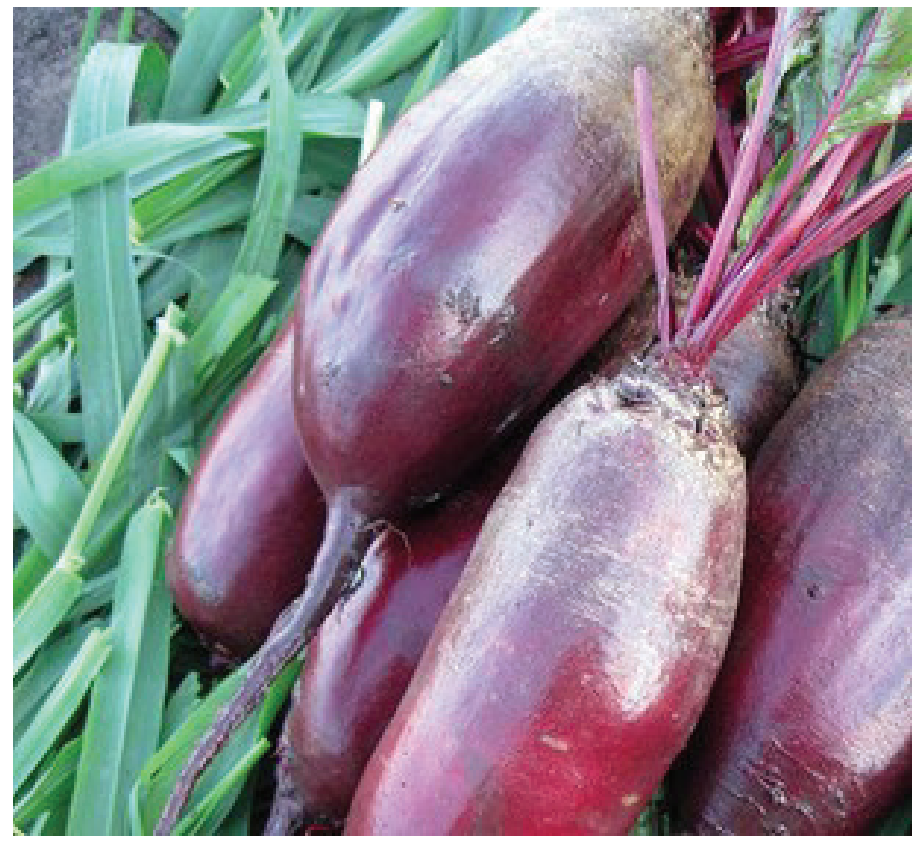

Fig. 2. Vital

Vital table beet are of the cylindrical oblong form with the form index (ratio between root length and diameter) from 4.2 to 4.5; Kharkiv Bordo - from 1 to 1.2. At the same diameter roots essentially differed by mass. Thus, at studying beetroots were divided by mass in three fractions: 500-700 g (big roots), 300-500 (middle) and 150-300 g (small roots). They were stored in nets (Fig. 3) at temperature $0 \pm 0.5^{\circ} \mathrm{C}$. 
After putting for storage, observations were conducted in dynamics with 1 month interval. A sample was excluded from storage, if natural mass losses reached $10 \%$ and more, and products had signs of damage by diseases and physiological disorders. For determining mass losses at storage of beetroots, each accounting sample (mass $5 \mathrm{~kg}$ ) [21] was weighted, numbered, recorded in a journal with a quality characteristic of roots.

There were determined: natural losses, root mass, damaged by diseases and sprouted ones; commodity products outlet at the end of storage.

Natural mass losses were determined by the formula:

$$
X=\frac{A-B}{A} \cdot 100,
$$

where $\mathrm{X}$ - mass loss, $\%$; A - products' mass at putting for storage, $\mathrm{g} ; B$-products' mass at the end of storage, $\mathrm{g}$.

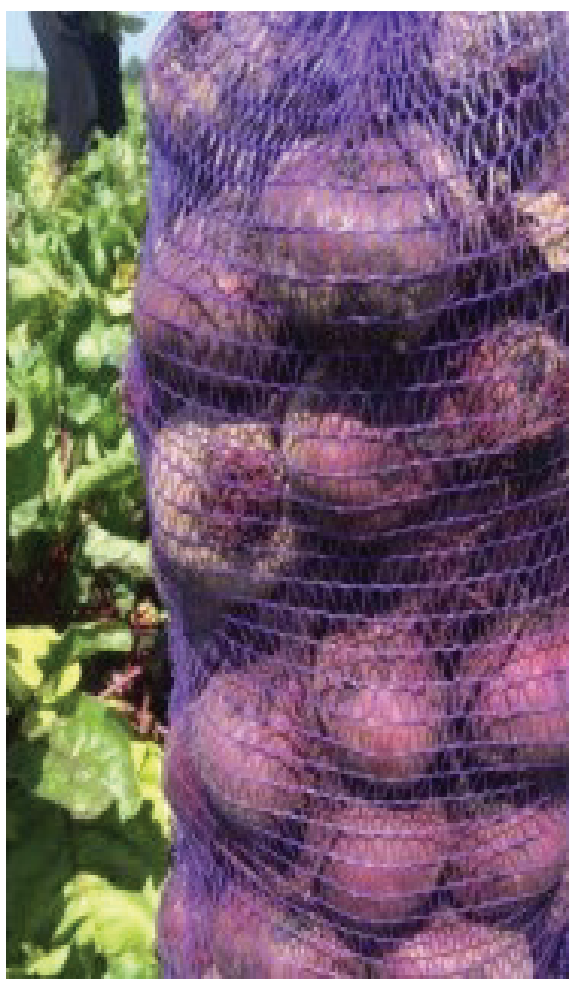

Fig. 3. Storage of table beet in nets

The statistical processing of the obtained results was conducted by the method of dispersion and correlation-regression analysis and using computer programs «Statistica 6» and MicrosoftExcel 2003.

The conducted studies were aimed at scientific substantiation of the influence of table beet sizes and forms on its storage life for determining its duration. The following tasks were set for attaining this aim:

- to determine natural mass losses of roots during storage;

- to determine the output of commodity products depending on root size.

\section{Results of studying the intensity of natural mass losses of table beet at storage}

Mass losses of roots at storage take place unevenly. At the beginning of storage, when the healing period has not finished yet, losses are rather high and are 1.3-1.7\% depending on sort 
peculiarities. Less mass losses are in Vital table beet - 1.3-1.5\%. Small Kharkiv Bordo beetroots lost mass in the first month of storage by $6.6 \%$ and $13.3 \%$ faster than middle and big roots, respectively. The analogous regularity of mass loss is in Vital roots.

Then mass losses gradually decrease to $0.5-0.9 \%$. At the storage period day mass losses in small roots varied from 0,034 in the Vital sort to $0,036 \%$ in Kharkiv Bordo, in middle size roots from 0,030 to $0,032 \%$, in big $-0,027-0,029 \%$ according to the sort (Table 1).

Table 1

Influence of table beet mass on natural mass losses at storage, $\%$

\begin{tabular}{ccccccc}
\hline Roots mass, $g$ & October & November & December & January & February & Totally \\
\hline & \multicolumn{7}{c}{ Kharkiv Bordo } \\
\hline $500-700$ & 1.5 & 1.1 & 0.7 & 0.6 & 0.5 & 4.4 \\
$300-500$ & 1.6 & 1.2 & 0.7 & 0.6 & 0.7 & 4.8 \\
$150-300$ & 1.7 & 1.3 & 0.8 & 0.7 & 0.9 & 5.4 \\
\hline $500-700$ & 1.3 & Vital & 0.6 & 0.6 & 0.6 & 4.1 \\
$300-500$ & 1.5 & 1.0 & 0.7 & 0.6 & 0.7 & 4.6 \\
$150-300$ & 1.6 & 1.2 & 0.8 & 0.7 & 0.8 & 5.1
\end{tabular}

As to sprouting, there were more sprouted roots among young small ones, than among more ripened. Already in January big and middle table beet became to sprout under conditions of the stationary artificially cooled warehouse, and small ones - no (Table 2).

Table 2

Storage life of table beet depending on their mass and sort peculiarities, $\%$

\begin{tabular}{ccccc}
\hline Roots mass, $\mathbf{g}$ & Natural mass losses & Sprouted & Average sprout length, cm & sick \\
\hline $500-700$ & Kharkiv Bordo & & \\
$300-500$ & 4.4 & 2.5 & 0.9 & 6.7 \\
$150-300$ & 4.8 & 2.2 & 0.9 & 6.8 \\
\hline $500-700$ & 5.4 & 1.8 & 0.5 & 12.3 \\
\hline $300-500$ & 4.1 & Vital & 0.9 & 4.5 \\
$150-300$ & 4.6 & 2.3 & 0.9 & 6.0 \\
& 5.1 & 2.0 & 0.5 & 10.4
\end{tabular}

Big and middle roots had longer sprouts than small ones. All not sick roots preserved the ability to sprout.

The studies have established that immature roots are less resistant to diseases, especially to rots [22]. At the storage period small roots were damaged by diseases (mainly gray rot) by $10.4 \%-12.3 \%$, whereas biggest - only by $4.5-4.7 \%$, and middle - by $6.0-68 \%$. The disease of the tail part of a root was observed. The commodity products output for 150 days of storage was $80.5-89.1 \%$ depending on root size (Fig. 4)

It has been established, that Vital table beet of the cylindrical form were stored better, than round Kharkiv Bordo ones: the commodity products output was by $0.7-2.9 \%$ higher. The storage life of big table beet is higher than of middle and small ones. The highest ability to sprouting was observed at withering. Big and middle roots must be put for long-term storage. It is better to allow big roots in normative documents and to exclude smalls ones completely. 


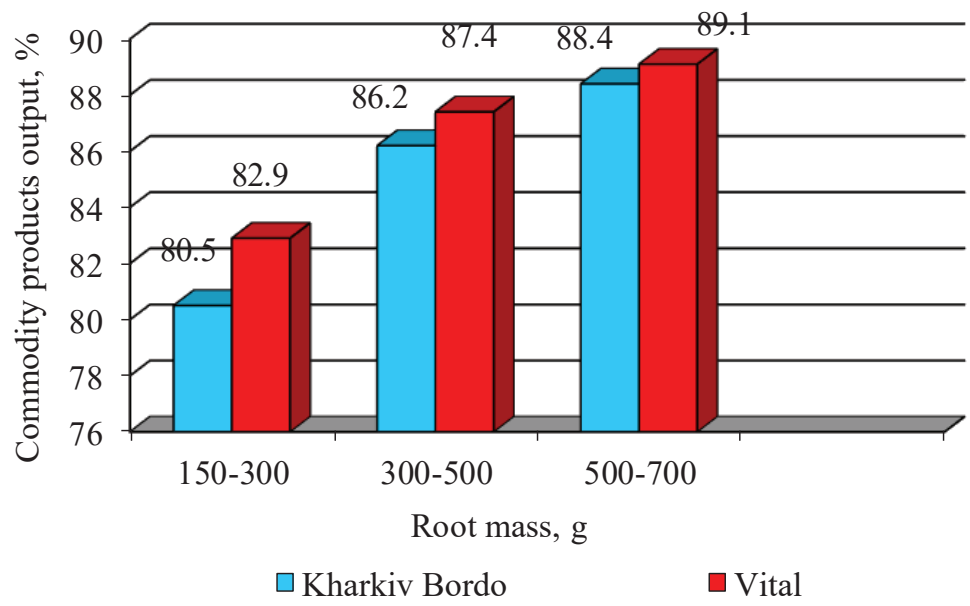

Fig. 4. Storage life of table beet depending on root size and sort peculiarities, $\%$

\section{Conclusions}

Less natural mass losses are inherent to big roots of 500-700 $\mathrm{g}-4.1-4.4 \%$, and more ones were in small roots $(150-300 \mathrm{~g})-5.1-5.4 \%$. At that less natural mass losses were observed in the Vital sort with roots of the cylindrical form.

More commodity products output at the end of storage was in the fraction of big roots of 500$700 \mathrm{~g}$ as $88.4-891 \%$. The fraction of small roots was characterized by the least commodity products output as $80.5-82.9 \%$. It must be noted, that cylindrical roots of the Vital sort were stored better.

\section{References}

[1] Pisarenko, V. V. Marketing ovoschnoy produktsii (metodicheskie i prakticheskie aspekty): Marketingovoe issledovanie potrebiteley, roznichnogo i optovogo segmenta rynka ovoschnoy produktsii. Agromage. Available at: https:/agromage.com/ stat_id.php?id=325

[2] Johnson, L. K., Bloom, J. D., Dunning, R. D., Gunter, C. C., Boyette, M. D., Creamer, N. G. (2019). Farmer harvest decisions and vegetable loss in primary production. Agricultural Systems, 176, 102672. doi: https://doi.org/10.1016/j.agsy.2019.102672

[3] Sych, Z. D., Fedosiy, I. O., Podpriatov, H. I. (2010). Pisliazbyralni tekhnolohiyi dorobky ovochiv dlia lohistyky i marketynhu. Kyiv, 440.

[4] Elik, A., Yanik, D. K., Istanbullu, Y., Guzelsoy, N. A., Yavuz, A., Gogus, F. (2019). Strategies to Reduce Post-Harvest Losses for Fruits and Vegetables. International Journal of Scientific and Technological Research, 5 (3), 29-39. doi: https://oi.org/ 10.7176/jstr/5-3-04

[5] Puzik, L. M., Hordienko, I. M. (2011). Tekhnolohiya zberihannia fruktiv, ovochiv ta vynohradu. Kharkiv: Maidan, 330.

[6] Yasaminshirazi, K., Hartung, J., Groenen, R., Heinze, T., Fleck, M., Zikeli, S., Graeff-Hoenninger, S. (2020). Agronomic Performance of Different Open-Pollinated Beetroot Genotypes Grown Under Organic Farming Conditions. Agronomy, 10 (6), 812. doi: https://doi.org/10.3390/agronomy10060812

[7] Wruss, J., Waldenberger, G., Huemer, S., Uygun, P., Lanzerstorfer, P., Müller, U. et. al. (2015). Compositional characteristics of commercial beetroot products and beetroot juice prepared from seven beetroot varieties grown in Upper Austria. Journal of Food Composition and Analysis, 42, 46-55. doi: https://doi.org/10.1016/j.jfca.2015.03.005

[8] Rubóczki, T., Raczkó, V., Takácsné Hájos, M. (2015). Evaluation of morphological parameters and bioactive compounds in different varieties of beetroot (Beta vulgaris L. ssp. esculenta GURKE var. rubra L.). International Journal of Horticultural Science, 21 (3-4), 31-35. doi: https://doi.org/10.31421/ijhs/21/3-4./1172

[9] Koltunov, V. A. (2007). Upravlinnia yakistiu ovochevykh koreneplodiv. Kyiv: KNTEU, 252.

[10] Vegetable Harvest Times. Available at: https://harvesttotable.com/vegetable_harvest_times/

[11] Koltunov, V., Bielinska, Ye. (2010). Obhruntuvannia efektyvnosti zberezhenosti redysu metodom Kharrinhtona. Tovary i rynky, 2, 62-68. Available at: http://nbuv.gov.ua/UJRN/tovary_2010_2_12

[12] Zherdetskyi, I. K. (2010). Osoblyvosti zberihannia matochnykh koreneplodiv. Propozytsiya, 11, 82-84.

[13] Zavadska, O. V., Bobos, I. M., Diadenko, T. V. (2013). Prydatnist koreneplodiv morkvy (Daucus carota L.) riznykh sortiv dlia pererobky. Sortovyvchennia ta okhorona prav na sorty roslyn, 1, 51-54. Available at: http://nbuv.gov.ua/UJRN/stopnsr_2013_1_13 
[14] DSTU 7033:2009 (2010). Fresh Table Beet. Specifications.

[15] Koltunov, V. A., Puzik, L. M. (2007). Porivnialna otsinka sposobiv zberihannia plodiv kabachka. Ovochivnytstvo i bashtannytstvo, 53, 354-359.

[16] Koltunov, V. A., Puzik, L. M., Vakulenko, L. M. (2006). Vplyv rozmiru ploda na zberezhenist kabachkiv, dyni, ohirkiv. Sbornik nauchnyh rabot Krymskogo gosudarstvennogo agrarnogo universiteta, 93, 56-60.

[17] Koltunov, V. A., Puzik, L. M. (2008). Formuvannia tovarnoho vrozhaiu kabachkiv. Zbirnyk naukovykh prats Umanskoho derzhavnoho ahrarnoho universytetu. Seriya: Ahronomiya, 67, 229-235.

[18] Koltunov, V. A., Puzik, L. M. (2006). Temperaturnyi stan produktsiyi harbuzovykh ovochiv pid chas zberihannia. Zbirnyk naukovykh prats KhNAU. Seriya: Roslynnytstvo, selektsiya, nasinnytstvo, ovochivnytstvo, 5, 220-222.

[19] Puzik, L. M. (2004). Teplofizychni vlastyvosti dyni. Ovochivnytstvo i bashtannytstvo, 49, 226-236.

[20] Bielinska, Ye. V. (2012). Tryvale zberihannia koreneplodiv redysky: naukove obhruntuvannia, praktychne zastosuvannia. Poltava: PUET, 152.

[21] DSTU ISO 874-2002. Fresh Fruits and Vegetables. Sampling.

[22] Ahatov, A. K. (2013). Bolezni i vrediteli ovoschnyh kul'tur i kartofelya. Moscow, 463.

Received date 01.02.2021

Accepted date 24.03.2021

Published date 31.03.2021
(C) The Author(s) 2021

This is an open access article under the CC BY license (http://creativecommons.org/licenses/by/4.0).

How to cite: Pusik, L., Pusik, V., Bondarenko, V., Gaevaya, L., Lyubymova, N., Sukhova, G., Didukh, N., Slobodianyk, G. (2021). Influence of form and size of a root on the storage life of kitchen beetroot. EUREKA: Life Sciences, 2, 65-72. doi: https://doi.org/ 10.21303/2504-5695.2021.001756 